\title{
Captured and Cross-Linked Palladium Nanoparticles
}

\author{
Jin Ku Cho, ${ }^{\dagger}$ Romain Najman, ${ }^{\dagger}$ Tony W. Dean, ${ }^{\ddagger}$ Osamu Ichihara, ${ }^{\S}$ Christophe Muller, ${ }^{\S}$ \\ and Mark Bradley*, $\dagger$ \\ ${ }^{\dagger}$ School of Chemistry, Joseph Black Building, King's Buildings, The University of \\ Edinburgh, West Mains Road, Edinburgh EH9 3JJ, United Kingdom, \\ * GlaxoSmithKline, Discovery Research, Gunnels Wood Road, Stevenage SG1 2NY, \\ United Kingdom \\ ${ }^{\S}$ Evotec Ltd, Milton Park, Abingdon, Oxfordshire OX14 4RZ, United Kingdom
}

\section{Supporting Information}

Preparation of XL-RC Palladium: In the $28 \mathrm{~mL}$-vial were put aminomethylated TentaGel resin (NovaSyn ${ }^{\circledR}$ TG amino resin HL, $1.00 \mathrm{~g}, 0.44 \mathrm{mmol}$ of $\mathrm{NH}_{2} / \mathrm{g}$ ) and palladium acetate $(100 \mathrm{mg}, 0.45 \mathrm{mmol})$ and toluene $(10 \mathrm{~mL})$ was added. The mixture was heated to $80{ }^{\circ} \mathrm{C}$ for $10 \mathrm{~min}$ and shaken at room temperature for $2 \mathrm{~h}$. The resin was filtered and washed with dichloromethane $(5 \times 20 \mathrm{~mL})$, methanol $(5 \times 20 \mathrm{~mL})$, and $N, N^{\prime}-$ dimethylforamide $(5 \times 20 \mathrm{~mL})$. The resin treated with $10 \%$ hydrazine hydrate in methanol $(10 \mathrm{~mL})$ (or prolonged stirring in toluene at $80{ }^{\circ} \mathrm{C}$ can also afford reduced $P d(0)$ without hydrazine treatment) gave $\mathrm{RC} \mathrm{Pd}$ catalyst of black color in $84 \%$ of capturing yield $(0.38 \mathrm{mmol}$ of $\mathrm{Pd} / \mathrm{g})$. The resulting resin was cross-linked with succinyl chloride $(24 \mu \mathrm{L}, 0.22 \mathrm{mmol})$ and triethylamine $(184 \mu \mathrm{L}, 1.32 \mathrm{mmol})$ in dry dichloromethane $(10 \mathrm{~mL})$. After shaking for $1 \mathrm{~h}$, the resin was filtered and washed with dichloromethane $(5 \times 20 \mathrm{~mL})$, methanol $(5 \times 20 \mathrm{~mL})$, and $N, N^{\prime}$-dimethylforamide $(5 \times 20$ 
$\mathrm{mL}$ ) and dried under reduced pressure to give final XL-RC Pd catalyst in $80 \%$ overall yield based on the amount of initially used palladium $(0.36 \mathrm{mmol}$ of $\mathrm{Pd} / \mathrm{g})$.

TEM analysis: Sample beads (RC-XL Pd) were embedded in Spurr resin and polymerized at $60{ }^{\circ} \mathrm{C}$ for $18 \mathrm{~h}$. $100 \mathrm{~nm}$ sections were cut on a Reichhert OMU3 ultramicrotome using a diamond knife. The sections were viewed on Hitachi H7000 transmission electron microscope.

Kinetic profile comparison: 4'-Bromoacetophenone (13 $\mathrm{mg}, 0.067 \mathrm{mmol}$, phenylboronic acid (10 mg, $0.08 \mathrm{mmol}, 1.2$ equiv), each supported palladium catalyst (10 mol\%), and potassium carbonate (28 mg, $0.2 \mathrm{mmol}, 3$ equiv) were loaded in $1.5 \mathrm{~mL}$ eppendorf tubes (same amount of 6 samples). Water $(300 \mu \mathrm{L})$ was added and the reaction mixture was stirred at $80{ }^{\circ} \mathrm{C}$. Each sample was quenched by adding cold water $(500 \mu \mathrm{L})$ and diethyl ether $(500 \mu \mathrm{L})$ after $5 \mathrm{~min}, 10 \mathrm{~min}, 30 \mathrm{~min}, 1 \mathrm{~h}, 2 \mathrm{~h}, 4 \mathrm{~h}$, respectively. The organic layer of each sample was analyzed by HPLC.

Filtration test: RC-XL Pd (140 mg, $0.36 \mathrm{mmol}$ of $\mathrm{Pd} / \mathrm{g}$ resin, $0.05 \mathrm{mmol}$ of $\mathrm{Pd}, 10$ mol\%) was loaded in 2-5 mL Emrys ${ }^{\mathrm{TM}}$ Process Vials. Water $(2 \mathrm{~mL})$ was added and the reactor was sealed by the septum. The RC-XL Pd was stirred at $80{ }^{\circ} \mathrm{C}$ for $20 \mathrm{~min}$ and then filtered while still hot. The filtrate was kept at $80{ }^{\circ} \mathrm{C}$ and $4^{\prime}$-bromoacetophenone (99 $\mathrm{mg}, 0.5 \mathrm{mmol})$, phenylboronic acid (73 mg, $0.6 \mathrm{mmol}, 1.2$ equiv), potassium carbonate (207 mg, $1.5 \mathrm{mmol}, 3$ equiv) were added. The reaction mixture was stirred for $3 \mathrm{~h}$ and the resulting crude following general workup procedure was analyzed by HPLC.

Three phase reaction: 4'-Bromoacetophenone (199 mg, $1 \mathrm{mmol}$ ), resin-bound 4'bromoaceto-phenonamide attached by Rink linker (24 mg, $0.01 \mathrm{mmol}, 0.01$ equiv), phenylboronic acid (183 mg, $1.5 \mathrm{mmol}, 1.5$ equiv), each supported palladium catalyst (5 
mol\%), and potassium carbonate (415 mg, $3 \mathrm{mmol}, 3$ equiv) were loaded in $2-5 \mathrm{~mL}$ Emrys $^{\mathrm{TM}}$ Process Vials from Personal Chemistry. Water $(5 \mathrm{~mL})$ was added and the reactor was sealed by the septum designed by Reseal ${ }^{\mathrm{TM}}$. The reaction mixture was stirred at $80{ }^{\circ} \mathrm{C}$ for $16 \mathrm{~h}$. Each resin-bound compounds and supported catalyst were filtered and washed with dichloromethane $(5 \times 3 \mathrm{~mL})$ and water $(5 \times 3 \mathrm{~mL})$. The combined filtrate was washed with water and the organic phase was separated and concentrated with reduced pressure. The resulting crude was purified by column chromatography on silica gel to give corresponding 4-acetyl biphenyl. On the other hand, the collected resins were treated with $90 \%$ trifluoroacetic acid in dichloromethane $(3 \mathrm{~mL})$ to release the products from resin. The resins was filtered and washed with dichloromethane $(3 \times 1 \mathrm{~mL})$. The combined filtrates was concentrated with positive nitrogen blowing and diluted with acetonitrile for HPLC analysis.

General procedure for aqueous Suzuki Coupling of aryl halides: Aryl halide (0.5 mmol), boronic acid (0.75 mmol, 1.5 equiv), potassium carbonate (1.5 mmol, 3 equiv), and XL-RC Pd catalyst (0.05 mmol, 0.1 equiv) were loaded into 2-5 mL Emrys ${ }^{\mathrm{TM}}$ Process Vials. Water $(2 \mathrm{~mL})$ was added and the reactor was sealed by the septum. The reaction mixture was stirred at $80{ }^{\circ} \mathrm{C}$ for $4-16 \mathrm{~h}$. At the conclusion of the reaction, the supported catalyst was filtered and washed with diethyl ether $(5 \times 3 \mathrm{~mL})$ and water $(5 \times 3$ $\mathrm{mL}$ ) by turns. The combined filtrate was washed with water and the organic phase was separated and concentrated with reduced pressure. The resulting crude was purified by column chromatography on silica gel to give final biaryl product.

4-Acetylbiphenyl (Table 1, entry 1). The general procedure gave $96 \mathrm{mg}$ (98\%) of white solid: ${ }^{1} \mathrm{H}$ NMR $\left(300 \mathrm{MHz}, \mathrm{CDCl}_{3}\right) \delta 8.05(\mathrm{~d}, 2 \mathrm{H}, J=8.1 \mathrm{~Hz}), 7.70(\mathrm{~d}, 2 \mathrm{H}, J=8.7 \mathrm{~Hz}), 7.65$ $(\mathrm{d}, 2 \mathrm{H}, J=8.1 \mathrm{~Hz}), 7.47-7.52(\mathrm{~m}, 2 \mathrm{H}), 7.43(\mathrm{~d}, 1 \mathrm{H}, J=6.6 \mathrm{~Hz}), 2.64(\mathrm{~s}, 3 \mathrm{H}) ;{ }^{13} \mathrm{C}$ NMR $(75$ $\left.\mathrm{MHz}_{\mathrm{CDCl}}\right) \delta 197.8,145.8,140.0,135.8,129.0,128.9,128.2,127.3,127.2,26.7$. 
4-Nitrobiphenyl (Table 1, entry 3). The general procedure gave $93 \mathrm{mg}$ (93\%) of pale yellow solid: ${ }^{1} \mathrm{H}$ NMR $\left(300 \mathrm{MHz}, \mathrm{CDCl}_{3}\right) \delta 8.30(\mathrm{~d}, 2 \mathrm{H}, J=8.7 \mathrm{~Hz}), 7.74(\mathrm{~d}, 2 \mathrm{H}, J=8.7$ $\mathrm{Hz})$, 7.61-7.65 (m, 2H), 7.45-7.53 (m, 3H); ${ }^{13} \mathrm{C} \mathrm{NMR}\left(75 \mathrm{MHz}, \mathrm{CDCl}_{3}\right) \delta$ 147.6, 138.7, $129.1,128.9,127.8,127.4,124.1$.

4-Methylbiphenyl (Table 1, entry 4). The general procedure gave $70 \mathrm{mg}(83 \%)$ of white solid: ${ }^{1} \mathrm{H}$ NMR $\left(300 \mathrm{MHz}, \mathrm{CDCl}_{3}\right) \delta 7.62(\mathrm{~d}, 2 \mathrm{H}, J=6.6 \mathrm{~Hz}), 7.54(\mathrm{~d}, 2 \mathrm{H}, J=8.1$ Hz), 7.46 (t, 2H, J=7.5 Hz), 7.36 (t, 1H, J=7.5 Hz), 7.29 (d, 2H, J=7.5 Hz), 2.44 (s, 3H); ${ }^{13} \mathrm{C}$ NMR $\left(75 \mathrm{MHz}, \mathrm{CDCl}_{3}\right) \delta 141.1,138.3,137.0,129.4,128.73,128.63,127.1,126.9$, 21.1.

2-Methylbiphenyl (Table 1, entry 5). The general procedure gave $61 \mathrm{mg}(72 \%)$ of colorless oil: ${ }^{1} \mathrm{H}$ NMR $\left(300 \mathrm{MHz}, \mathrm{CDCl}_{3}\right) \delta$ 7.42-7.47 (m, 2H), 7.34-7.39 (m, 3H), 7.26$7.30(\mathrm{~m}, 4 \mathrm{H}), 2.30(\mathrm{~s}, 3 \mathrm{H}) ;{ }^{13} \mathrm{C} \mathrm{NMR}\left(75 \mathrm{MHz}, \mathrm{CDCl}_{3}\right) \delta 141.9,138.9,135.3,130.3$, $129.8,129.2,128.0,127.2,126.7,125.7,20.5$.

4-Methoxybiphenyl (Table 1, entry 6). The general procedure gave $87 \mathrm{mg}$ (94\%) of white solid: ${ }^{1} \mathrm{H}$ NMR (300 MHz, $\left.\mathrm{CDCl}_{3}\right) \delta$ 7.52-7.56 (m, 4H), 7.41 (t, 2H, J=7.4 Hz), $7.30(\mathrm{t}, 1 \mathrm{H}, J=7.2 \mathrm{~Hz}), 6.98(\mathrm{~d}, 2 \mathrm{H}, J=8.7 \mathrm{~Hz}), 3.84(\mathrm{~s}, 3 \mathrm{H}) ;{ }^{13} \mathrm{C}$ NMR $\left(75 \mathrm{MHz}, \mathrm{CDCl}_{3}\right)$ $\delta 159.1,138.2,133.8,128.7,128.2,126.8,126.7,114.2,55.4$.

2,4-Dimethoxybiphenyl (Table 1, entry 7). The general procedure gave $67 \mathrm{mg}$ (63\%) of colorless oil: ${ }^{1} \mathrm{H}$ NMR $\left(300 \mathrm{MHz}, \mathrm{CDCl}_{3}\right) \delta 7.53(\mathrm{~d}, 2 \mathrm{H}, J=8.1 \mathrm{~Hz}), 7.42(\mathrm{t}, 2 \mathrm{H}, J=8.1$ $\mathrm{Hz}), 7.33$ (d, 1H, J=7.2 Hz), 7.27 (d, 1H, $J=9.0 \mathrm{~Hz}), 6.58-6.62$ (m, 2H), 3.88 (s, 3H), 3.82 $(\mathrm{s}, 3 \mathrm{H}) ;{ }^{13} \mathrm{C} \mathrm{NMR}\left(75 \mathrm{MHz}, \mathrm{CDCl}_{3}\right) \delta 157.4,138.3,131.2,129.4,127.9,126.5,123.5$, 104.5, 98.9, 55.5, 55.4 . 
4-Methyl-4'-methoxybiphenyl (Table 1, entry 8). The general procedure gave $81 \mathrm{mg}$ (82\%) of white solid: ${ }^{1} \mathrm{H}$ NMR $\left(300 \mathrm{MHz}, \mathrm{CDCl}_{3}\right) \delta 7.52$ (d, 2H, J=9.0 Hz), 7.46 (d, 2H, $J=8.1 \mathrm{~Hz}), 7.24(\mathrm{~d}, 2 \mathrm{H}, J=8.1 \mathrm{~Hz}), 6.98(\mathrm{~d}, 2 \mathrm{H}, J=9.0 \mathrm{~Hz}), 3.86(\mathrm{~s}, 3 \mathrm{H}), 2.40(\mathrm{~s}, 3 \mathrm{H}) ;{ }^{13} \mathrm{C}$ NMR (75 MHz, $\left.\mathrm{CDCl}_{3}\right) \delta 158.9,138.0,136.4,133.7,129.5,128.0,126.6,114.2,55.4$, 21.1.

2-Methyl-4'-methoxybiphenyl (Table 1, entry 9). The general procedure gave $61 \mathrm{mg}$ (62\%) of colorless oil: ${ }^{1} \mathrm{H}$ NMR $\left(300 \mathrm{MHz}, \mathrm{CDCl}_{3}\right) \delta 7.25-7.30(\mathrm{~m}, 6 \mathrm{H}), 6.98(\mathrm{~d}, 2 \mathrm{H}$, $J=8.7 \mathrm{~Hz}), 3.88$ (s, 3H), 2.31 (s, 3H); ${ }^{13} \mathrm{C} \mathrm{NMR}\left(300 \mathrm{MHz}, \mathrm{CDCl}_{3}\right) \delta 158.5,141.5,135.5$, $134.3,130.2,129.9,126.9,125.7,113.4,55.3,20.5$.

4-Methoxy-4'-methoxybiphenyl (Table 1, entry 10). The general procedure gave 97 mg (91\%) of white solid: ${ }^{1} \mathrm{H}$ NMR $\left(300 \mathrm{MHz} \mathrm{CDCl}_{3}\right) \delta 7.49(\mathrm{~d}, 4 \mathrm{H}, J=8.7 \mathrm{~Hz}), 6.97$ (d, $4 \mathrm{H}, J=9.0 \mathrm{~Hz}), 3.85(\mathrm{~s}, 6 \mathrm{H}) ;{ }^{13} \mathrm{C} \mathrm{NMR}\left(300 \mathrm{MHz}, \mathrm{CDCl}_{3}\right) \delta 158.6,133.4,127.7,114.1$, 55.3 .

Recycle Test for aqueous Suzuki Coupling of 4-acetophenyl bromide and phenylboronic acid: After aqueous Suzuki coupling, XL-RC Pd catalyst was collected, washed, dried, and reused for next cycle. Each cycle followed the general procedure for aqueous Suzuki coupling of aryl halide to give corresponding product in $99 \%$ (1st use), 98\% (2nd use), 98\% (3rd use), 98\% (4th use), 98\% (5th use), 97\% (6th use) yield based on HPLC.

\section{Bromophenol blue derivatives (Table 2).}

Bromophenol blue (0.5 mmol), carboxyphenylboronic acid (0.6 mmol, 1.2 equiv), potassium phosphate ( $1.5 \mathrm{mmol}, 3$ equiv), and XL-RC Pd catalyst ( $0.05 \mathrm{mmol}, 0.1$ equiv) 
were loaded into Emrys ${ }^{\mathrm{TM}}$ Process Vials. Water $(5 \mathrm{~mL})$ was added and the reactor was sealed by the septum. The reaction mixture was irradiated by microwave at $120{ }^{\circ} \mathrm{C}$ for 10 min. At the conclusion of the reaction, the supported catalyst was filtered and washed with ethyl acetate, water, and saturated $\mathrm{KHSO}_{4}$ solution by turns. The combined filtrate was extracted with ethylacetate, dried over $\mathrm{Na}_{2} \mathrm{SO}_{4}$, and evaporated under reduced pressure to afford a reddish oil. The product was isolated by column chromatography on

silica gel (chloroform:methanol:acetic acid=5:1:0.06) to give the desired bromophenol blue derivative in $41 \%$ yield: ${ }^{1} \mathrm{H}$ NMR $\left(400 \mathrm{MHz}, 5 \% \mathrm{CF}_{3} \mathrm{CO}_{2} \mathrm{D}\right.$ in $\left.\mathrm{CD}_{3} \mathrm{CN}\right): \delta=8.03(\mathrm{~d}$, $2 \mathrm{H}, J=8.4), 7.95(\mathrm{~d}, 1 \mathrm{H}, J=6.8), 7.82(\mathrm{t}, 1 \mathrm{H}, J=7.6), 7.74(\mathrm{t}, 1 \mathrm{H}, J=7.8), 7.58(\mathrm{~d}, 1 \mathrm{H}$, $J=7.6), 7.54(\mathrm{~d}, 2 \mathrm{H}, J=8.4), 7.47(\mathrm{~d}, 1 \mathrm{H}, J=2.4), 7.45(\mathrm{~s}, 2 \mathrm{H}), 7.17(\mathrm{~d}, 1 \mathrm{H}, J=2.0)$; a calculated mass for $\mathrm{C}_{26} \mathrm{H}_{15} \mathrm{Br}_{3} \mathrm{O}_{7} \mathrm{~S}$ : 711.2, found: ESI-MS, $m / z$, negative [M-H] : 708.4, 710.6 .

\section{Bromocresol purple derivatives (Table 2).}

Bromocresol purple (0.5 mmol), carboxyphenylboronic acid (0.6 mmol, 1.2 equiv), potassium phosphate ( $1.5 \mathrm{mmol}, 3$ equiv), and XL-RC Pd catalyst ( $0.05 \mathrm{mmol}, 0.1$ equiv) were loaded into Emrys ${ }^{\mathrm{TM}}$ Process Vials. Water $(5 \mathrm{~mL})$ was added and the reactor was sealed by the septum. The reaction mixture was irradiated by microwave at $120{ }^{\circ} \mathrm{C}$ for 10 min. At the conclusion of the reaction, the supported catalyst was filtered and washed with ethyl acetate, water, and saturated $\mathrm{KHSO}_{4}$ solution by turns. The combined filtrate was extracted with ethylacetate, dried over $\mathrm{Na}_{2} \mathrm{SO}_{4}$, and evaporated under reduced pressure to afford a reddish oil. The product was isolated by column chromatography on silica gel (chloroform:methanol=5:1) to give the desired bromocresol purple derivative in 57\% yield: ${ }^{1} \mathrm{H}$ NMR (400 MHz, 5\% $\mathrm{CF}_{3} \mathrm{CO}_{2} \mathrm{D}$ in $\mathrm{CD}_{3} \mathrm{CN}$ ): $\delta=8.03(\mathrm{~d}, 2 \mathrm{H}, J=8.0 \mathrm{~Hz}$ ), $7.91(\mathrm{~d}, 1 \mathrm{H}, J=8.0 \mathrm{~Hz}), 7.78(\mathrm{t}, 1 \mathrm{H}, J=7.6 \mathrm{~Hz}), 7.71(\mathrm{t}, 1 \mathrm{H}, J=7.6 \mathrm{~Hz}), 7.51-7.54(\mathrm{~m}$, $3 \mathrm{H}), 7.27(\mathrm{~d}, 1 \mathrm{H}, J=2.4 \mathrm{~Hz}), 7.11(\mathrm{~d}, 1 \mathrm{H}, J=2.4 \mathrm{~Hz}), 7.09$ (s, 2H, $J=2.8 \mathrm{~Hz}), 6.99$ (d, $1 \mathrm{H}, J=2.8 \mathrm{~Hz}), 2.23(\mathrm{~s}, 3 \mathrm{H}), 2.21(\mathrm{~s}, 3 \mathrm{H})$; a calculated mass for $\mathrm{C}_{28} \mathrm{H}_{21} \mathrm{BrO}_{7} \mathrm{~S}: 581.4$, found: ESI-MS, $m / z$, negative $[\mathrm{M}-\mathrm{H}]]^{-}: 579.3,581.3$. 


\section{Bromothymol blue derivatives (Table 2).}

Bromothymol blue (0.5 mmol), carboxyphenylboronic acid (0.6 mmol, 1.2 equiv), potassium phosphate ( $1.5 \mathrm{mmol}, 3$ equiv), and XL-RC Pd catalyst ( $0.05 \mathrm{mmol}, 0.1$ equiv) were loaded into Emrys ${ }^{\mathrm{TM}}$ Process Vials. Water $(5 \mathrm{~mL})$ was added and the reactor was sealed by the septum. The reaction mixture was irradiated by microwave at $120{ }^{\circ} \mathrm{C}$ for 10 min. At the conclusion of the reaction, the supported catalyst was filtered and washed with ethyl acetate, water, and saturated $\mathrm{KHSO}_{4}$ solution by turns. The combined filtrate was extracted with ethylacetate, dried over $\mathrm{Na}_{2} \mathrm{SO}_{4}$, and evaporated under reduced pressure to afford a reddish oil. The crude product was purified by column chromatography on silica gel (chloroform:methanol $=5: 1$ ) to give the desired bromothylmol blue derivative in $28 \%$ yield: ${ }^{1} \mathrm{H}$ NMR $\left(400 \mathrm{MHz}, 5 \% \mathrm{CH}_{3} \mathrm{CO}_{2} \mathrm{D}\right.$ in $\left.\left(\mathrm{CD}_{3}\right)_{2} \mathrm{SO}, 100{ }^{\circ} \mathrm{C}\right): \delta=7.94-8.01(\mathrm{~m}, 3 \mathrm{H}), 7.16-7.36(\mathrm{~m}, 6 \mathrm{H}), 6.93(\mathrm{t}, 1 \mathrm{H}, J=7.6 \mathrm{~Hz})$, 2.96-3.12 (br, 2H), 2.19 (s, 1,5H, rotamer), $2.11(\mathrm{~s}, 1.5 \mathrm{H}$, rotamer), $1.63(\mathrm{~s}, 1.5 \mathrm{H}$, rotamer $), 1.54(\mathrm{~s}, 1.5 \mathrm{H}$, rotamer $), 0.97-1.03(\mathrm{~m}, 12 \mathrm{H}) ;$ a calculated mass for $\mathrm{C}_{34} \mathrm{H}_{33} \mathrm{BrO}_{7} \mathrm{~S}: 665.6$, found: ESI-MS, $m / z$, negative [M-H] $]^{-}$664.6, 662.7. 


\section{IR spectra}

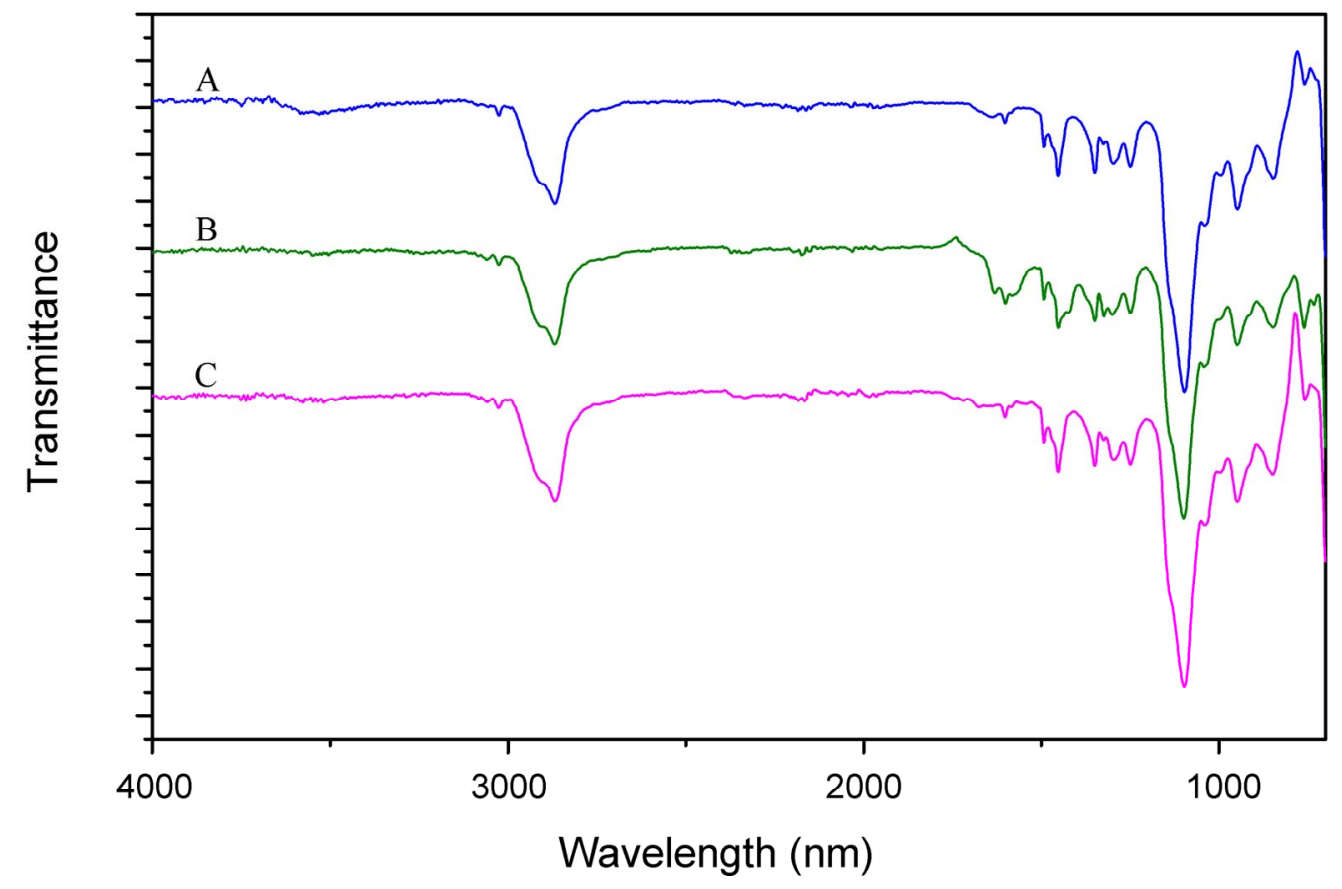
(A) Original aminomethylated TentaGel resin
(B) Resin-captured (RC) $\operatorname{Pd}(\mathrm{OAc})_{2}$
(C) $\mathrm{RC} \mathrm{Pd}$ after $\mathrm{NH}_{2} \mathrm{NH}_{2} \cdot \mathrm{H}_{2} \mathrm{O}$ treatment

Figure S1. IR spectra of RC Pd after $\mathrm{NH}_{2} \mathrm{NH}_{2} \cdot \mathrm{H}_{2} \mathrm{O}$ treatment. 


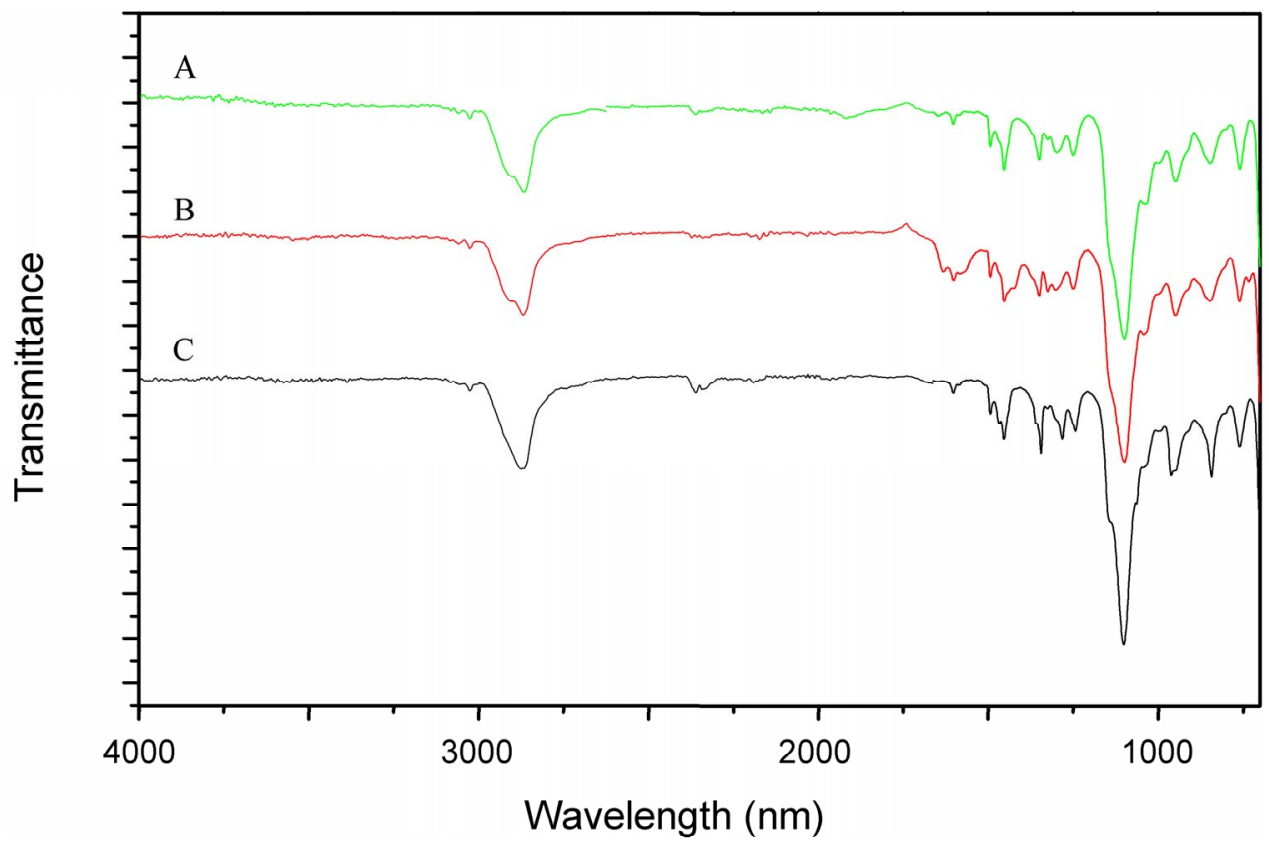
(A) Original aminomethylated TentaGel resin
(B) Resin-captured (RC) Pd(OAc) $)_{2}$
(C) RC Pd after prolonged stirring in toluene at $80{ }^{\circ} \mathrm{C}$

Figure S2. IR spectra of RC Pd after prolonged stirring in toluene at $80^{\circ} \mathrm{C}$. 
SEM
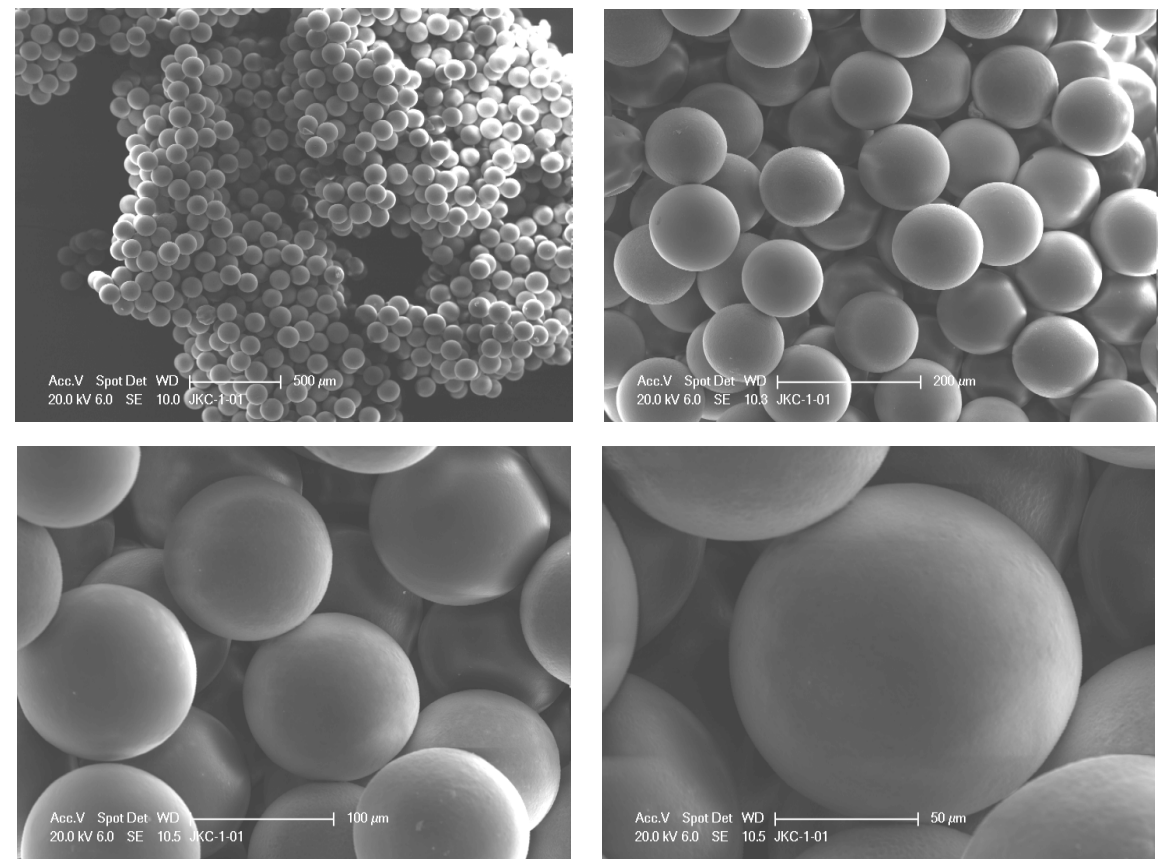

Figure S3. SEM of XL-RC Pd.

\section{SEM-EDX}

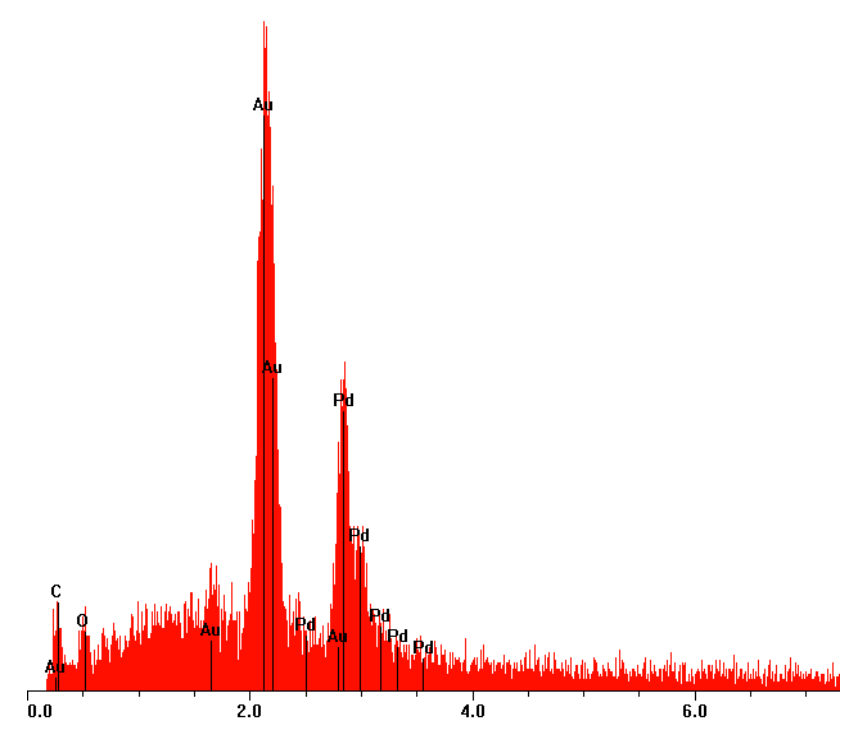

Figure S4. SEM-EDX of XL-RC Pd. 


\section{TEM}

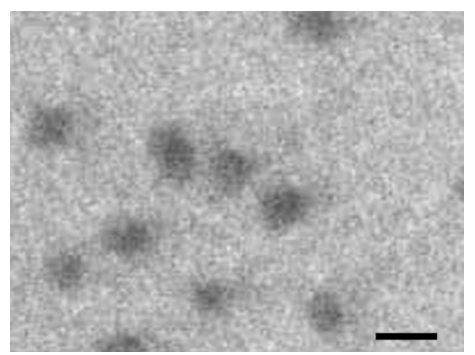

(a) XL-RC Pd
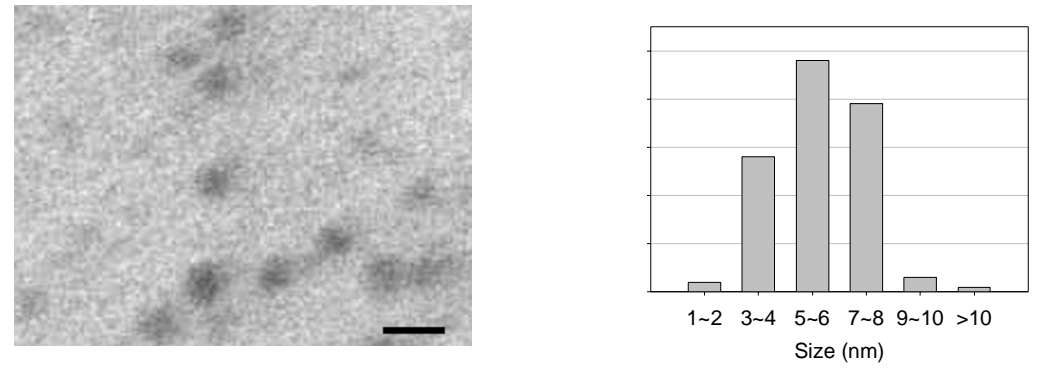

(b) XL-RC Pd after 2nd use
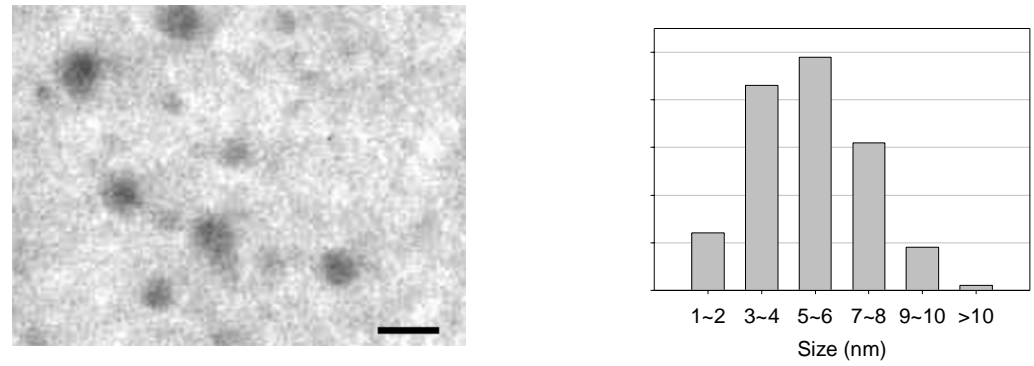

(c) XL-RC Pd after 5th use
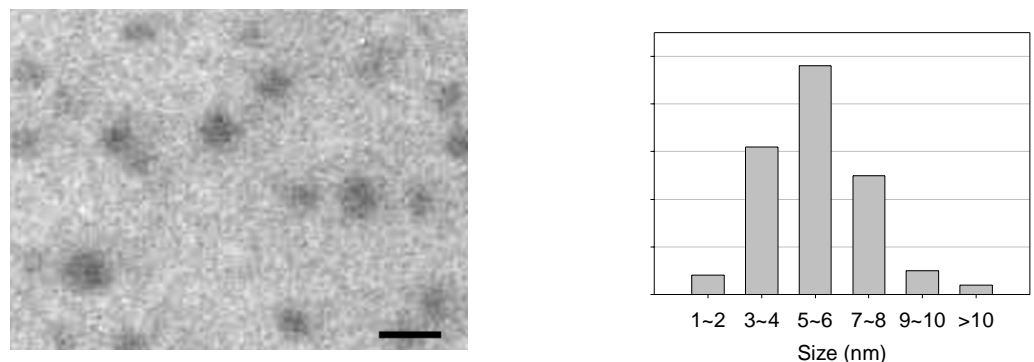

(d) XL-RC Pd after 6th use

Figure S5. TEM images of XL RC Pd after reuses (scale bar: $10 \mathrm{~nm}$ ). 